Article

\title{
Long-Term Assessment of Periodontal Tissues after Corticotomy-Assisted Orthodontic Arch Expansion
}

\author{
Magdalena Ewa Sulewska ${ }^{1, * \mathbb{C}}$, Amelia Baczewska ${ }^{1}$, Beata Bugała-Musiatowicz ${ }^{2}$, \\ Emilia Waszkiewicz-Sewastianik ${ }^{3}$, Jan Krzysztof Pietruski ${ }^{3}$ and Małgorzata Pietruska ${ }^{1,3}$ \\ 1 Department of Periodontal and Oral Mucosa Diseases, Medical University of Bialystok, ul. Waszyngtona 13, \\ 15-269 Białystok, Poland; amelia.baczewska@umb.edu.pl (A.B.); malgorzata.pietruska@umb.edu.pl (M.P.) \\ 2 Dental Practice, ul. Żeromskiego 1A/1U, 15-349 Białystok, Poland; beatryczeort@o2.pl \\ 3 Dental Practice, ul. Waszyngtona 1/34, 15-269 Białystok, Poland; milkanet@interia.pl (E.W.-S.); \\ janpietruski@wp.pl (J.K.P.) \\ * Correspondence: magdalena.sulewska@umb.edu.pl
}

\section{check for}

updates

Citation: Sulewska, M.E.; Baczewska, A.; Bugała-Musiatowicz,

B.; Waszkiewicz-Sewastianik, E.;

Pietruski, J.K.; Pietruska, M.

Long-Term Assessment of

Periodontal Tissues after

Corticotomy-Assisted Orthodontic

Arch Expansion. J. Clin. Med. 2021, 10,

5588. https://doi.org/10.3390/

jcm10235588

Academic Editor: Peter Proff

Received: 6 November 2021

Accepted: 23 November 2021

Published: 27 November 2021

Publisher's Note: MDPI stays neutral with regard to jurisdictional claims in published maps and institutional affiliations.

Copyright: (c) 2021 by the authors. Licensee MDPI, Basel, Switzerland. This article is an open access article distributed under the terms and conditions of the Creative Commons Attribution (CC BY) license (https:// creativecommons.org/licenses/by/ $4.0 /)$.

\begin{abstract}
Objectives: The aim of the study was the long-term assessment of the condition of periodontal tissues after corticotomy-assisted orthodontic expansion in patients with transverse maxillary deficiency. Materials and Methods: The study included a group of 18 adults ( 9 women, 9 men) aged between 24 and 40 years who were at least 5 years post treatment. The following parameters were assessed: the full mouth plaque index (FMPI), full mouth bleeding on probing (FMBOP), probing depth (PD), clinical attachment level (CAL), gingival recession height (GR), recession width (RW), papilla height $(\mathrm{PH})$, papilla width $(\mathrm{PW})$, bone sounding $(\mathrm{BS})$, phenotype, and KT. Results: During examination performed at least 5 years after the completion of orthodontic treatment, the values of PD and CAL were found to be considerably decreased compared to the examination one year post treatment (PD: -0.23 ; 95\% Cl: $-0.29,-0.16)(\mathrm{CAL}:-0.04 ; 95 \% \mathrm{Cl}$ : $-0.17,0.10)$. The other parameters-FMPI, FMBOP, GR, RW, PH, PW, BS, phenotype, and KT—did not change significantly. Conclusions: Corticotomy-assisted orthodontic arch expansion does not have a negative effect on the periodontium in long-term observations. Clinical Relevance: Orthodontic arch expansion can lead to bone dehiscence and gingival recession. Long-term observations revealed that corticotomy-assisted orthodontic expansion of the upper arch is not followed by negative changes in periodontal status.
\end{abstract}

Keywords: orthodontic arch expansion; corticotomy; soft tissues

\section{Introduction}

Maintaining a healthy periodontium is the key to maintaining a fully functional stomatognathic system. All procedures should be carried out in a way that prevents damage to the structures of periodontal tissues and enables the beneficial effects after the applied treatment to be maintained in the long term. Orthodontic treatment of patients with transverse maxillary deficiency can lead to adverse changes in the bone and soft tissues. As a result of the expansion of the dental arch, particularly in patients with the thin phenotype, it is highly probable to develop bone dehiscence and gingival recession [1-5]. The consequences of gingival recession, in addition to the aesthetic problem, may include loss of hard dental tissues and tooth sensitivity [6,7]. The treatment of this type of complication requires significant financial resources and additionally burdens the patient. Furthermore, it does not offer the possibility of reconstructing the lost bone or soft tissues, which may generate further adverse changes in the long-term observations [8]. Therefore, in order to limit the negative effects of arch expansion on periodontal tissues, additional methods supporting orthodontic treatment are sought. A basic type of treatment, especially recommended to patients with a thin phenotype, is gingival augmentation with the use of autogenous bone grafts or biomaterials as a form of prevention of gingival recession $[9,10]$. A completely different concept is corticotomy, which consists of the cutting of buccal and/or palatal compact 
bone plate, generating the regional acceleratory phenomenon (RAP). RAP is a cascade of physiological events leading to increased bone turnover accompanied by demineralization and the formation of a new bone at the site of injury [11-14]. Due to this phenomenon, when orthodontic force is applied, not only the tooth but also the adjacent demineralized bone matrix is displaced, which potentially reduces the risk of bone dehiscence and the subsequent gingival recession [15-22]. It should be remembered that bone apposition is also stimulated by properly performed orthodontic treatment [23].

The currently available literature data do not provide a clear answer as to whether the use of corticotomy prior to orthodontic arch expansion prevents adverse bone and soft tissue changes [24-35]. Moreover, there are no long-term data evaluating periodontal changes after this type of treatment.

In the light of the above, the aim of this study was to assess the periodontium condition at least five years after the combined surgical and orthodontic treatment of patients with maxillary narrowing.

\section{Materials and Methods}

The study was designed as a case series study. The study involved 20 patients treated in the years 2011-2014. Patients with transverse maxillary deficiency, scheduled for corticotomy-supported orthodontic treatment of the upper dental arch, qualified for the study. The sample size calculation was made in G*POWER software using 0.2 effect size and power $=0.9$. The aim of performing corticotomy was to prevent bone dehiscence and gingival recession.

The inclusion criteria were as follows: voluntary participation, adult ( $>18$ years old), non-smoker, generally healthy, with malocclusion with transverse maxillary deficiency with indications for upper arch expansion, good oral hygiene and motivation at screening quantified as: full mouth plaque index (FMPI) $<20 \%$, full mouth bleeding on probing (FM$\mathrm{BOP})<20 \%$. The exclusion criteria were the following diseases or conditions: periodontal disease and oral mucosa lesions, bisphosphonate and long-term corticosteroid therapy, current therapy with anti-epileptic drugs, contraceptives, estrogen, antihistamine drugs, calcitonin, vitamin $\mathrm{D}$, alcohol and/or drug addiction, the presence of periapical endoperiolesions, severe gingival recession, pregnancy, breast feeding, previous orthodontic treatment and root resorption. Within the study group, the following malocclusions were diagnosed: Class I with crowding — six patients; Class I with lateral crossbite-three patients; Class I with bilateral crossbite-two patients; Class II Division 1—one patient; Class II Division 1 with anterior open bite-two patients; Class II Division 2-one patient; and Class III with a skeletal relationship-five patients.

The surgery was done in maxilla under local anesthesia with $4 \%$ articaine (Ubistesin forte, 3 M ESPE, Maplewood, MN, USA). The mucoperiosteal flap was elevated up to the point above the apical parts of roots following modified papilla preservation technique as well as performing vertical releasing incisions [36]. Then, osteotomy of the buccal cortical plate of the alveolar process was performed by using OTS7, OTS7-4, and OTS7-3 ultrasound tips of the piezosurgery device (Mectron S.p.A., Carasco, Italy). The extension of the osteotomy was determined by the mesio-distal dimension of the teeth roots as well as by the position of the apexes of roots. In order to avoid interproximal bone pick resorption, the vertical cuts ended $5 \mathrm{~mm}$ apically from the crest and then spread in a Y-shape towards the neighboring teeth. The horizontal corticotomy was performed approximately $2-4 \mathrm{~mm}$ apically above the root apexes. The depth of the cuts was limited to the thickness of the cortical plate. The repositioned flap was sutured with non-resorbable monofilament 5.0 and 6.0 sutures (Resolon, Resorba Medical GmbH, Nümberg, Germany). One gram of amoxicillin 2×/day for 7 days, $200 \mathrm{mg}$ of ibuprofen $3 \times /$ day, and mouth rinsing with chlorhexidine $(0.10 \%$ Eludril, Pierre Fabre Sante, Paris, France) $2 \times /$ day were prescribed, and gentle tooth brushing using an ultra-soft post-surgical toothbrush and the roll technique in the surgical area for two weeks after the surgery was recommended to the patients. The supragingival plaque was cleaned out 7 and 14 days after the surgery. The sutures were removed 
14 days post-op, and tooth brushing with a soft toothbrush and the roll technique was recommended. The detailed methodology and post-treatment results are presented in the publication from 2018 [25].

A check-up was performed 5-8 years after corticotomy (on average, after 6.5 years). The examination was participated in by 18 subjects ( 9 women, 9 men) aged from 26 to 46 years. Two patients ( 1 female and 1 male) did not attend the examination due to the COVID-19 pandemic. All clinical examinations were performed by the same doctor.

The following parameters were assessed: the full mouth plaque index (FMPI), full mouth bleeding on probing (FMBOP), probing depth (PD), clinical attachment level (CAL), gingival recession height $(\mathrm{GR})$, recession width $(\mathrm{RW})$, papilla height $(\mathrm{PH})$, papilla width (PW), bone sounding (BS), phenotype and keratinized tissue (KT).

The measurements were performed using a manual PCP UNC 15 periodontal probe (Hu-Friedy, Chicago, IL, USA) by one calibrated investigator. All measurements were rounded to the nearest $0.5 \mathrm{~mm}$.

Phenotype-gingival thickness was measured under anaesthesia at mid-facial aspect of the tooth on a long axis $1 \mathrm{~mm}$ apically from the bottom of the sulcus with the use of K-file 25 ISO with a silicone marker [37]. Keratinized tissue (KT) was measured from the most apical point of gingival margin to the mucogingival junction.

The study was conducted in accordance with the Helsinki Declaration of 1975, as revised in 2000, and was reviewed and approved by the local ethical committee (Ethics Committee No.: R-I-002/344/2011).

\section{Statistical Analysis}

The variables were described by the parameters of descriptive statistics, i.e., arithmetic mean, standard deviation, median, lower and upper quartile, and minimum and maximum value. The normality of distribution was tested using the Shapiro-Wilk test. ANOVA, MANOVA with Tukey's post hoc HSD test, or Friedman's test with Dunn's multiple comparisons test with Bonferroni correction (depending on the assumptions fulfilled) were used for comparing the three groups. For differences between the measurements (one year vs. a minimum of 5 years after the treatment), the mean values with $95 \%$ confidence interval and standard deviation are provided. For statistical analyses, a significance level of $p<0.05$ was assumed. The analyses were performed using the PQStat program, version 1.8.0.476.

\section{Results}

During the follow-up examination, 142 teeth were examined-one molar had been previously extracted due to endodontic complications.

It was found that one year after corticotomy and at least five years later, FMPI and FMBOP values were comparable (Table 1).

Table 1. Full mouth plaque index (FMPI) and full mouth bleeding on probing (FMBOP) before, 1 year and a minimum of 5 years after orthodontic treatment.

\begin{tabular}{|c|c|c|c|c|c|}
\hline Parameter & [\%] & Time of Observation & $\begin{array}{l}\text { Difference between } 1 \text { Year and a } \\
\text { Minimum of } 5 \text { Years Post-op }\end{array}$ & $p$-Value & $\begin{array}{l}\text { Mean Diff. }(95 \% \mathrm{Cl}) \text { between } 1 \text { Year } \\
\text { and a Minimum of } 5 \text { Years Post-op }\end{array}$ \\
\hline FMPI & $\mathrm{x} \pm \mathrm{SD}$ & $\begin{array}{c}\text { Baseline } 17.33 \pm 2.11 \\
1 \text { year } 16.90 \pm 2.25 \\
5 \text { years } 17.20 \pm 2.18\end{array}$ & $+0.30 \%$ & $p=0.699 *$ & $\begin{array}{c}0.42 \\
(-0.91,1.75)\end{array}$ \\
\hline FMBOP & $\mathrm{x} \pm \mathrm{SD}$ & $\begin{array}{c}\text { Baseline } 13.44 \pm 1.87 \\
1 \text { year } 13.24 \pm 1.75 \\
5 \text { years } 13.32 \pm 1.46\end{array}$ & $+0.08 \%$ & $p=0.724^{* *}$ & $\begin{array}{c}0.26 \\
(-0.61,1.12)\end{array}$ \\
\hline
\end{tabular}

$\mathrm{x} \pm \mathrm{SD}-$ mean values and standard deviation; Mean diff.-mean difference; $\mathrm{Cl}$-confidence interval; ${ }^{*}$ Tukey's post hoc HSD test (ANOVA);

** Tukey's post hoc HSD test (MANOVA).

In the examinations performed at least five years post treatment, we observed a significant reduction in PD and CAL compared to the examination conducted one year 
after treatment. The values of PD decreased from $2.48 \pm 0.51$ to $2.28 \pm 0.48 \mathrm{~mm}$, and those of CAL decreased from $2.49 \pm 0.51$ to $2.48 \pm 0.86 \mathrm{~mm}$ (Table 2).

Table 2. Probing depth (PD), clinical attachment level (CAL), bone sounding (BS) before, 1 year and a minimum of 5 years after the corticotomy-assisted orthodontic treatment.

\begin{tabular}{|c|c|c|c|c|c|}
\hline Parameter & {$[\mathrm{mm}]$} & Time of Observation & $\begin{array}{l}\text { Difference between } 1 \text { Year and } \\
\text { a Minimum of } 5 \text { Years Post-op }\end{array}$ & $p$-Value & $\begin{array}{c}\text { Mean Diff. (95\% Cl) between } \\
1 \text { Year and a Minimum of } \\
5 \text { Years Post-op }\end{array}$ \\
\hline PD & $\mathrm{x} \pm \mathrm{SD}$ & $\begin{array}{c}\text { Baseline } 2.74 \pm 0.57 \\
1 \text { year } 2.48 \pm 0.51 \\
5 \text { years } 2.28 \pm 0.48\end{array}$ & $-0.20 \mathrm{~mm}$ & $p<0.0001 *$ & $\begin{array}{c}-0.23 \\
(-0.29,-0.16)\end{array}$ \\
\hline CAL & $\mathrm{x} \pm \mathrm{SD}$ & $\begin{array}{c}\text { Baseline } 2.75 \pm 0.57 \\
1 \text { year } 2.49 \pm 0.51 \\
5 \text { years } 2.48 \pm 0.86\end{array}$ & $-0.01 \mathrm{~mm}$ & $p=0.0350 *$ & $\begin{array}{c}-0.04 \\
(-0.17,0.10)\end{array}$ \\
\hline BS & $\mathrm{x} \pm \mathrm{SD}$ & $\begin{array}{c}\text { Baseline } 4.76 \pm 0.94 \\
1 \text { year } 4.49 \pm 0.77 \\
5 \text { years } 4.29 \pm 0.70\end{array}$ & $-0.20 \mathrm{~mm}$ & $p=0.2430 *$ & $(-1.43,-0.79)$ \\
\hline
\end{tabular}

$\mathrm{x} \pm \mathrm{SD}$-mean values and standard deviation; Mean diff.-mean difference; $\mathrm{Cl}$-confidence interval; ${ }^{*}$ Dunn's multiple comparisons test with Bonferroni correction (Friedman).

One year post treatment, 8/159 (5.03\%) gingival recessions of Miller Class I were found. In the follow-up examination, the number of gingival recessions increased to 9/142 (6.34\%). The values of all the other analyzed parameters, viz: GR, RW, PH, PW, BS, phenotype and $\mathrm{KT}$, did not change significantly during the evaluated observation period. Detailed numerical data related to these parameters are included in Table 3. Figures 1-4 present the clinical status of one of the patients-before the treatment, during corticotomy procedures, as well as one year and six years after the corticotomy procedure.

Table 3. Biotype, papilla width (PW), papilla height (PH), gingival recession (GR), recession width (RW) and keratinized tissue (KT) before, 1 year and a minimum of 5 years after the corticotomy-assisted orthodontic treatment.

\begin{tabular}{|c|c|c|c|c|c|}
\hline Parameter & {$[\mathrm{mm}]$} & Time of Observation & $\begin{array}{l}\text { Difference between } 1 \text { Year and a } \\
\text { Minimum of } 5 \text { Years Post-op }\end{array}$ & $p$-Value & $\begin{array}{c}\text { Mean Diff. (95\% Cl) between } 1 \text { Year } \\
\text { and } 5 \text { Years Post-op }\end{array}$ \\
\hline Phenotype & $\mathrm{x} \pm \mathrm{SD}$ & $\begin{array}{c}\text { Baseline } 1.71 \pm 0.52 \\
1 \text { year } 2.03 \pm 0.47 \\
5 \text { years } 1.99 \pm 0.50\end{array}$ & $-0.04 \mathrm{~mm}$ & $p=1$ * & $\begin{array}{c}-0.02 \\
(-0.05,0.02)\end{array}$ \\
\hline PW & $\mathrm{x} \pm \mathrm{SD}$ & $\begin{array}{c}\text { Baseline } 3.75 \pm 0.92 \\
1 \text { year } 3.54 \pm 1.50 \\
5 \text { years } 4.03 \pm 0.89\end{array}$ & $+0.49 \mathrm{~mm}$ & $p=0.103 *$ & $\begin{array}{c}0.38 \\
(0.18,0.58)\end{array}$ \\
\hline $\mathrm{PH}$ & $\mathrm{x} \pm \mathrm{SD}$ & $\begin{array}{l}\text { Baseline } 4.82 \pm 1.16 \\
1 \text { year } 4.00 \pm 1.60 \\
5 \text { years } 4.29 \pm 3.56\end{array}$ & $+0.29 \mathrm{~mm}$ & $p=0.057^{*}$ & $\begin{array}{c}0.19 \\
(-0.40,0.78)\end{array}$ \\
\hline GR & $\mathrm{x} \pm \mathrm{SD}$ & $\begin{array}{c}\text { Baseline } 0.13 \pm 0.47 \\
1 \text { year } 0.07 \pm 0.32 \\
5 \text { years } 0.19 \pm 0.79\end{array}$ & $+0.12 \mathrm{~mm}$ & $p=1^{*}$ & $\begin{array}{c}0.11 \\
(0.01,0.21)\end{array}$ \\
\hline RW & $x \pm S D$ & $\begin{array}{c}\text { Baseline } 0.21 \pm 0.75 \\
1 \text { year } 0.10 \pm 0.49 \\
5 \text { years } 0.14 \pm 0.59\end{array}$ & $+0.04 \mathrm{~mm}$ & $p=1^{*}$ & $\begin{array}{c}0.02 \\
(-0.07,0.12)\end{array}$ \\
\hline KT & $\mathrm{x} \pm \mathrm{SD}$ & $\begin{array}{c}\text { Baseline } 5.02 \pm 1.79 \\
\text { 1year } 5.12 \pm 1.78 \\
5 \text { years } 5.12 \pm 1.72\end{array}$ & $0.00 \mathrm{~mm}$ & $p=1 *$ & $\begin{array}{c}-0.03 \\
(-0.23,0.18)\end{array}$ \\
\hline
\end{tabular}

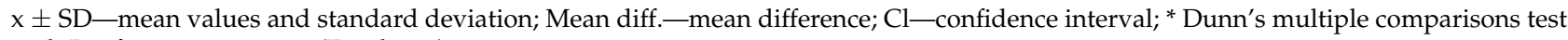
with Bonferroni correction (Friedman). 


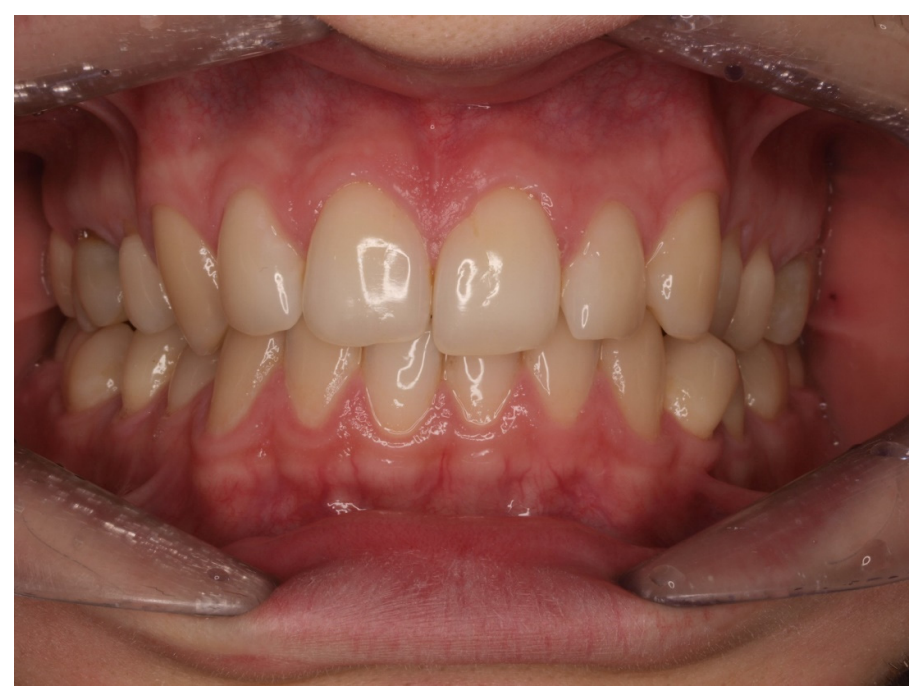

(a)

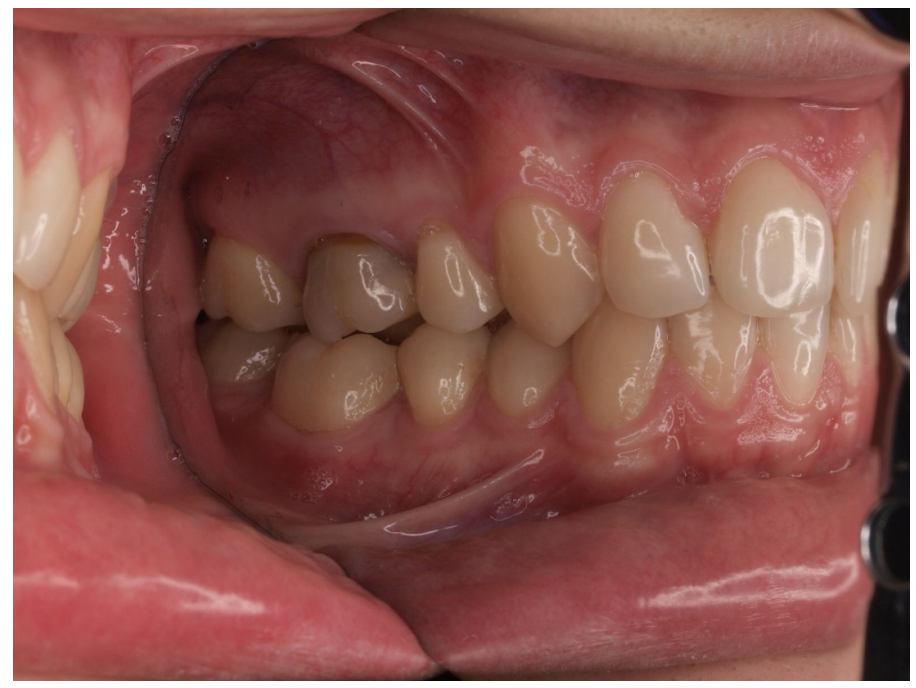

(b)

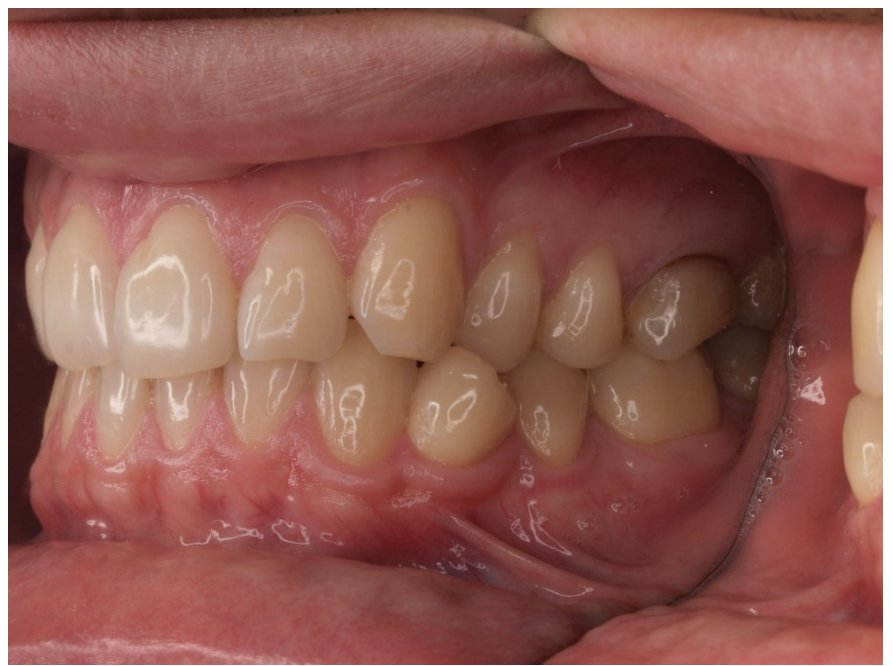

(c)

Figure 1. (a) Status before orthodontic treatment-lateral crossbite (left side). (b) Status before orthodontic treatment-right side. (c). Status before orthodontic treatment-left side. 


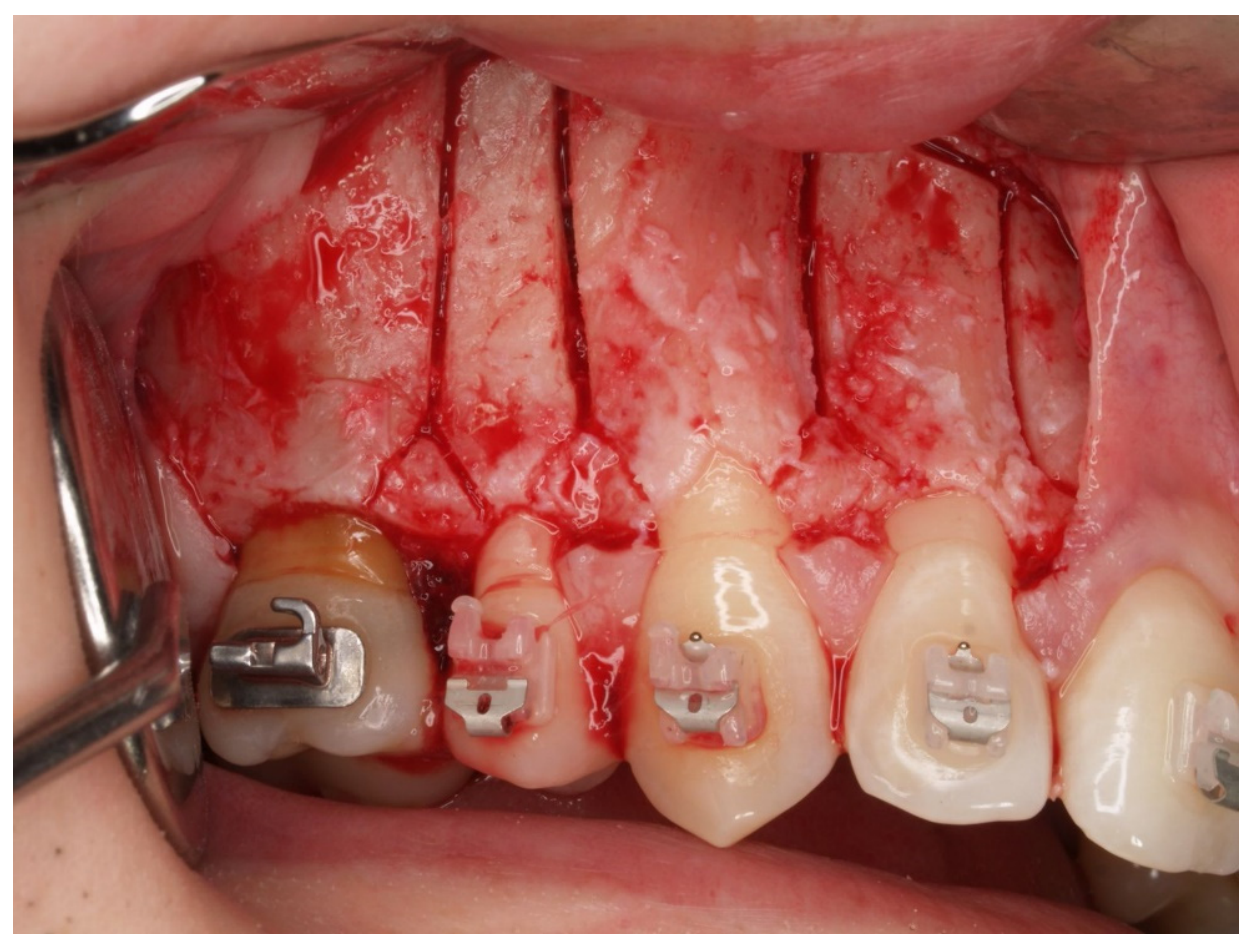

(a)

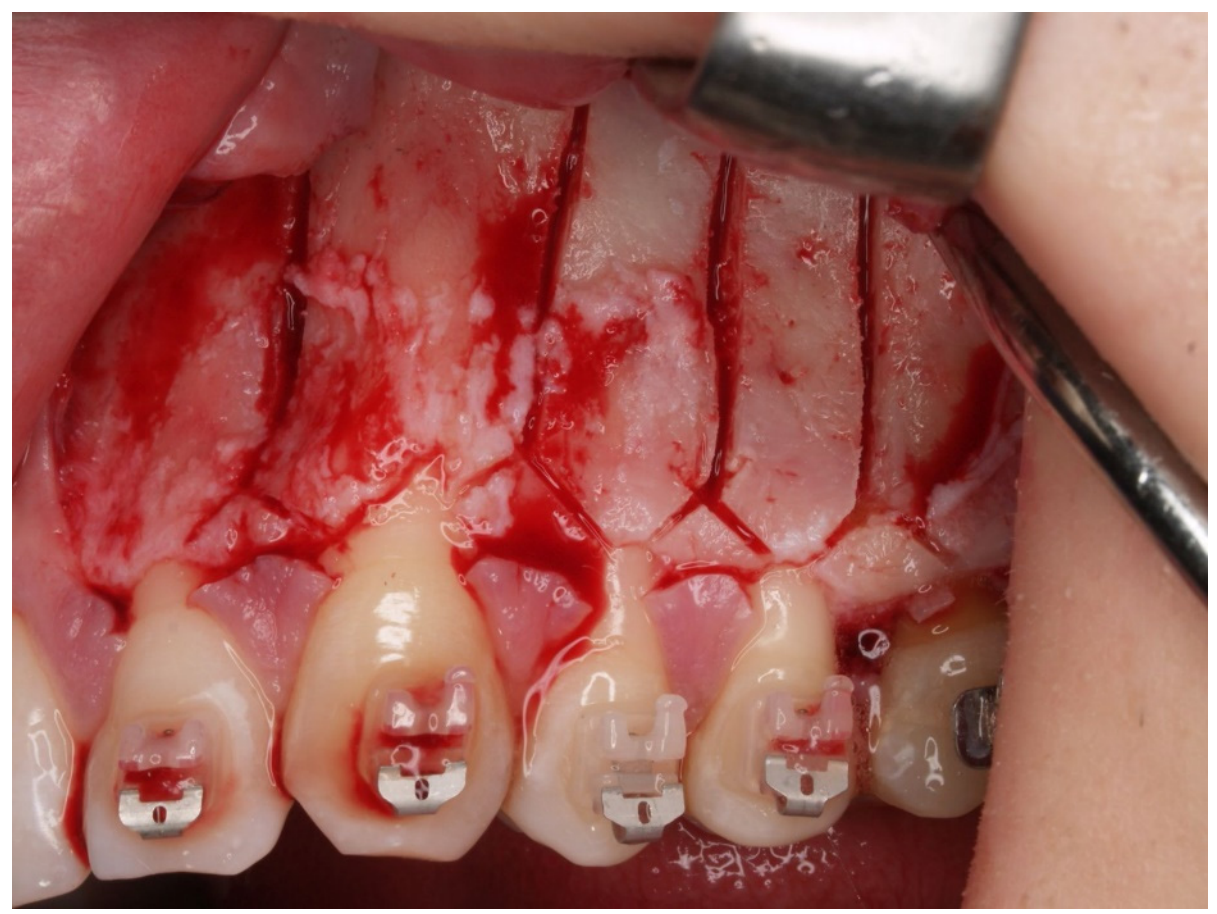

(b)

Figure 2. (a) Corticotomy in the area of the upper lateral incisor, canine and premolars. Incision of the cortical plate in the interdental spaces and above the apexes of the teeth-right side. (b) Corticotomy in the area of the upper canine and premolars. Incision of the cortical plate in the interdental spaces and above the apexes of the teeth-left side. 


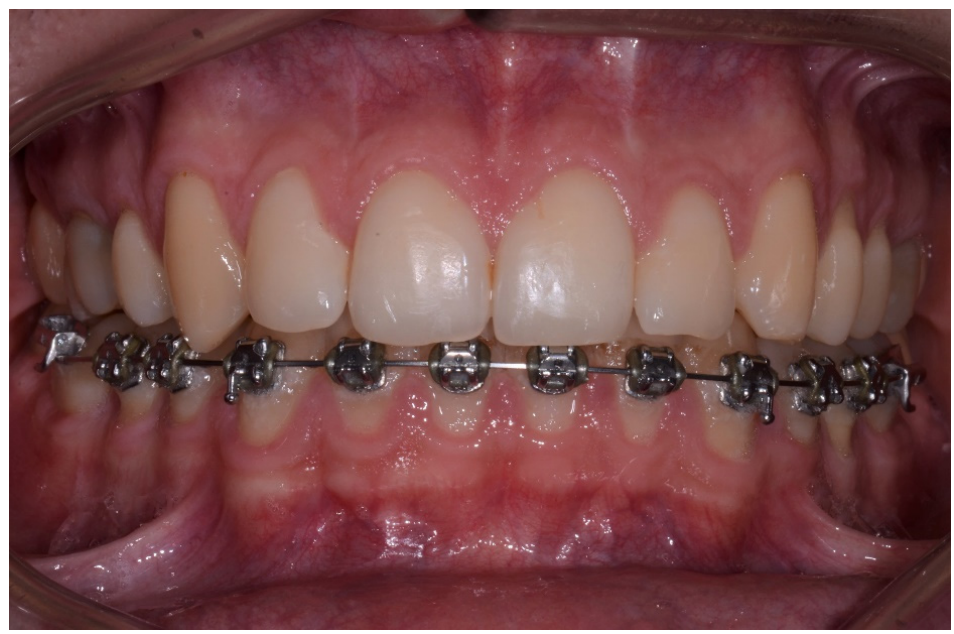

(a)

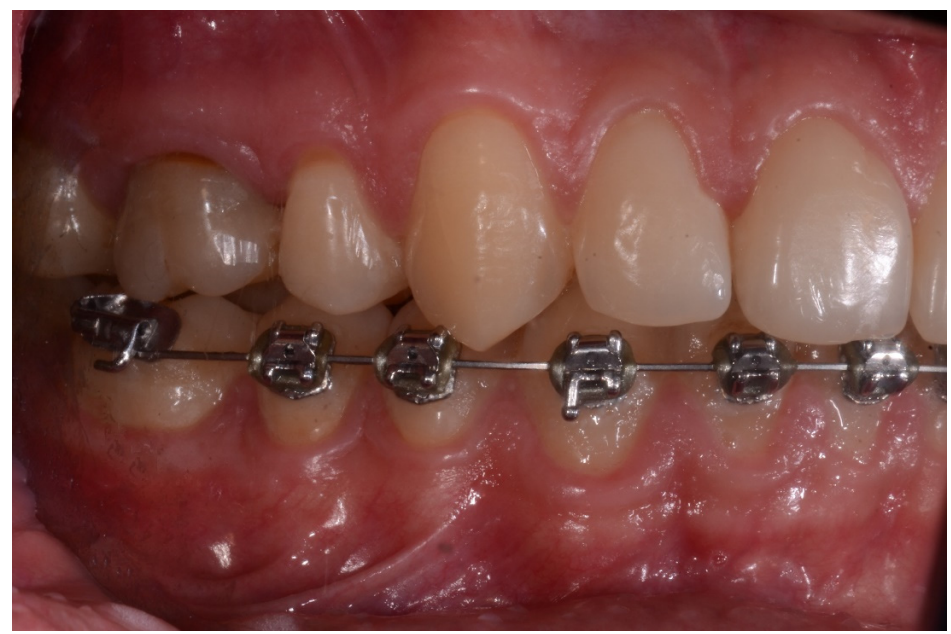

(b)

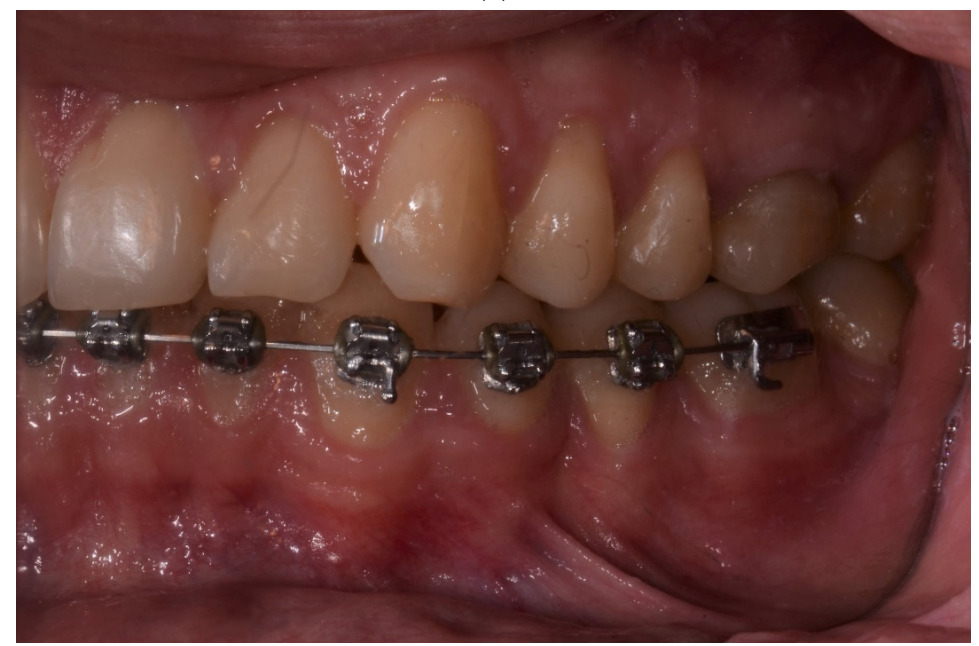

(c)

Figure 3. (a) Status one year after orthodontic treatment completion. There are no evident adverse changes in the position of the gingival margin after labial tooth movement. (b) Status one year after orthodontic treatment completion. There are no evident adverse changes in the position of the gingival margin after labial tooth movement-right side. (c) Status one year after orthodontic treatment completion. There are no evident adverse changes in the position of the gingival margin after labial tooth movement-left side. 


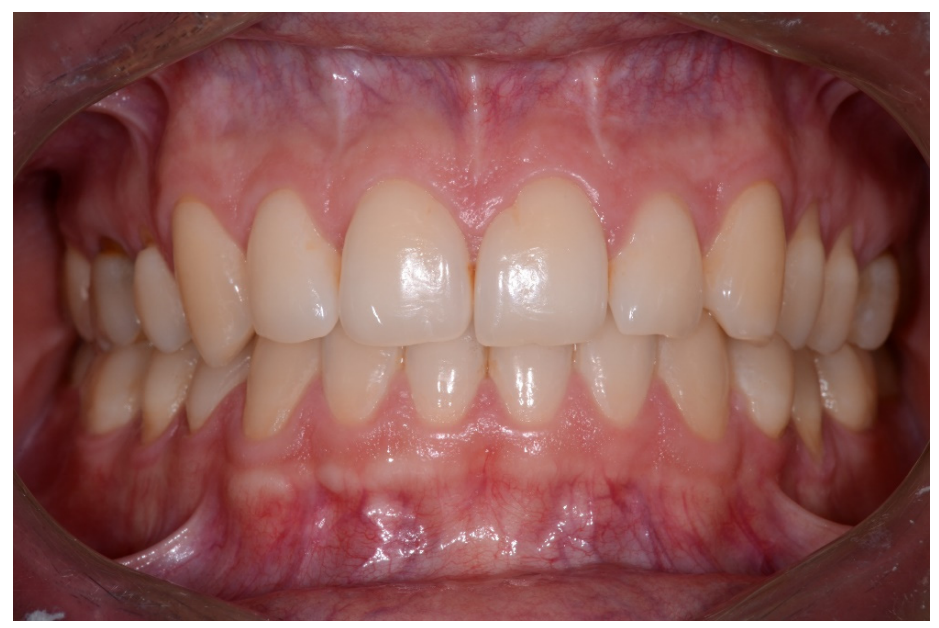

(a)

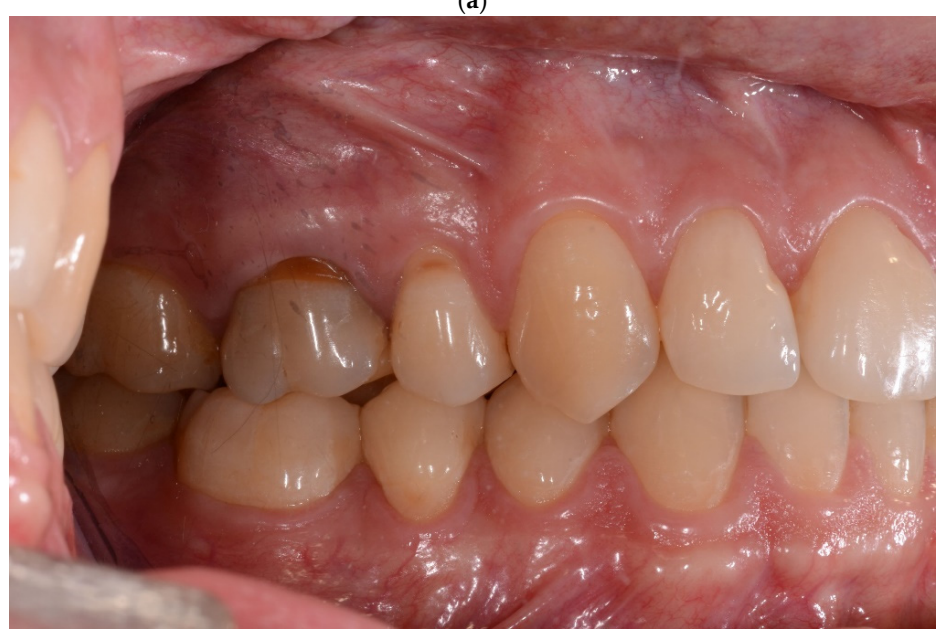

(b)

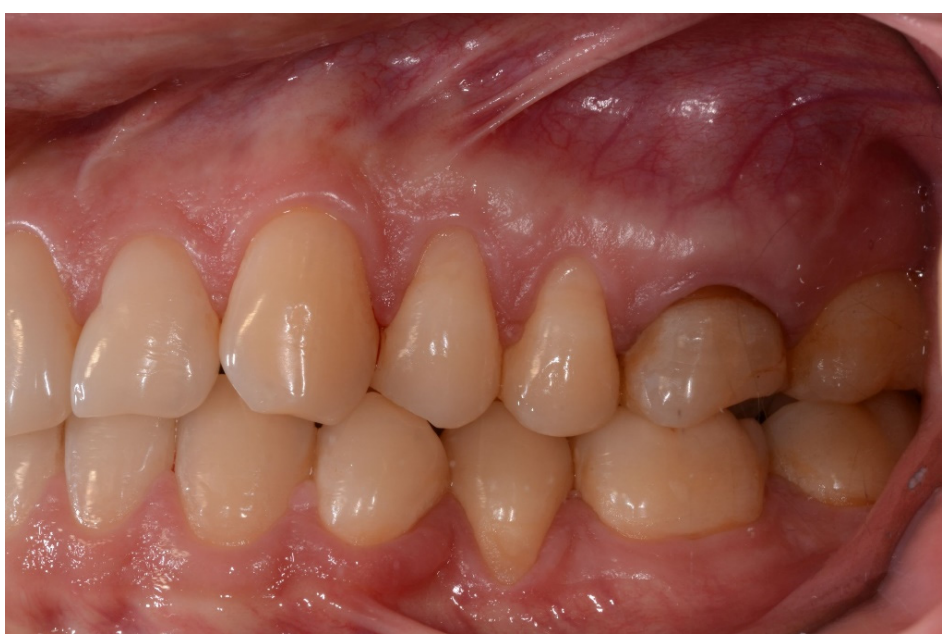

(c)

Figure 4. (a) Status six years after orthodontic treatment completion. The position of the gingival margin one year and six years after treatment is comparable. (b) Status six years after orthodontic treatment completion. The position of the gingival margin one year and six years after treatment is comparable-right side. (c) Status six years after orthodontic treatment completion. The position of the gingival margin one year and six years after treatment is comparable-left side. 


\section{Discussion}

The aim of the presented study was to analyze possible changes in the periodontium after corticotomy-assisted orthodontic expansion of the maxillary dental arch in a long-term observation. The clinical examination involved evaluation of numerous parameters which enabled a detailed qualitative and quantitative assessment of the soft tissues as well as the position of the margin of the buccal cortical plate. No adverse changes were found in the periodontal tissues - the values of most parameters remained similar to those obtained one year after the procedure. Moreover, the values of PD and CAL were significantly reduced, by 0.2 and $0.01 \mathrm{~mm}$, respectively, which emphasizes the stability of periodontal tissues over time.

The available literature lacks detailed multidirectional studies evaluating periodontal changes after combined surgical and orthodontic treatment. Nevertheless, most publications report the lack of negative effects of this type of treatment on the periodontium, based on such parameters as PD, CAL, BOP, or the number of gingival recessions $[22,30,31,33,38-46]$. Data published in a systematic review in 2020 indicate that PD values in short-term observations not exceeding 20 months decrease by $0.32-0.58 \mathrm{~mm}$ [47]. According to some authors, the reduction in this parameter is statistically significant at $0.58,0.427$ and $0.36 \mathrm{~mm}[27,28,48]$. Other researchers reported an insignificant reduction in PD by 0.2 , 0.323 or $0.25 \mathrm{~mm}[24,31,35]$.

The literature data concerning CAL changes after the discussed therapeutic procedure are very limited. The available data suggest that either no changes in CAL values were observed after treatment, or the reduction in CAL in short-term observations was $0.1 \mathrm{~mm}[24,32,33]$.

Our study revealed that the only adverse change over time was the appearance of 1 gingival recession of $2 \mathrm{~mm}$ in height. The recession appeared on the tooth adjacent to the extracted one; therefore, it can be assumed that it was the result of soft tissue deformation associated with tooth extraction. In contrast, the increase in mean height of the gingival recession was $0.12 \mathrm{~mm}$ and was not statistically significant. The obtained results may be related to the use of appropriate minimally invasive techniques aimed at preserving gingival papillae intact [49]. The absence of newly formed gingival recessions in shortterm observations of three and four months was also reported by other authors $[30,32,33]$. Studies comparing the orthodontic-surgical procedure with classical orthodontic treatment are also noteworthy. It has been demonstrated that after orthodontic treatment with corticotomy, the value of GR decreased insignificantly by $0.07 \mathrm{~mm}$ (from $0.49 \pm 0.26 \mathrm{~mm}$ to $0.42 \pm 0.3 \mathrm{~mm}$ ), while classical orthodontic treatment entailed its insignificant increase by $0.64 \mathrm{~mm}$ (from $0.55 \pm 0.31$ to $1.19 \pm 0.24 \mathrm{~mm}$ ) [31].

It should be emphasized that the discussed therapeutic procedure had no negative effects on the quantity and quality of soft tissues, i.e., their phenotype (gingival thickness) and KT, in the long-term observations. These parameters improved significantly a year after the procedure compared to their baseline value (phenotype by $0.32 \mathrm{~mm}$, KT by $0.1 \mathrm{~mm}$ ) and remained at a comparable level for an average of 6.5 years. These results seem optimistic compared to those obtained after classical orthodontic treatment. Indeed, a significant reduction in gingival thickness was demonstrated in the region of the maxillary (by $0.15-0.35 \mathrm{~mm}$ ) and mandibular (by $0.18-0.3 \mathrm{~mm}$ ) anterior teeth after their displacement in the sagittal plane [50]. A mean reduction in the KT height of $0.25 \mathrm{~mm}$ immediately after conventional treatment has also been reported [51]. According to other authors, a significant reduction in KT width occurred only in maxillary lateral incisors after protrusive movement, giving rise to the hypothesis that there is a positive relationship between sagittal tooth displacement and KT width [50].

A mean reduction in the KT height of $0.25 \mathrm{~mm}$ has also been reported immediately after conventional treatment [51]. According to other authors, a significant decrease in KT width occurred only with maxillary lateral incisors after protrusive movement, leading to the conclusion that there is a positive relationship between sagittal tooth displacement and KT width [50]. This thesis was confirmed by Wang et al. [52], who reported that 
displacement of teeth during orthodontic treatment affects the width of the keratinized gingiva, and an increase in positive torque results in a greater likelihood of reducing the width of the keratinized gingiva. However, there are no literature data evaluating gingival thickness after combined surgical and orthodontic treatment.

The available literature also contains negative statements regarding orthodonticsurgical treatment. Some authors claim that adverse effects of this procedure include increased gingival recession and alveolar bone loss due to the existing periodontal diseases or premature removal of sutures $[15,47,53]$. These statements may seem rather controversial, especially in view of the fact that treatment is performed in the presence of coexisting inflammation. According to data obtained by other researchers as well as our own experience, such factors as appropriate patient selection, oral hygiene regime, absence of inflammation, and the precision of the surgical procedure minimize the risk of the abovementioned problems. Therefore, corticotomy-assisted orthodontic arch expansion appears to be a safe procedure that ensures long-term stability of periodontal tissues. Several authors even suggest the possibility of an osteogenic effect of alveolar corticotomy [54-57].

A major limitation of this study is the lack of a control group, the small sample size and the single examiner. The lack of a control group results from ethical constraints. The approval of the bioethics committee was obtained for the corticotomy procedure and not for other procedures protecting periodontal tissues, such as soft tissue augmentation. Thus, it is difficult to explain whether or not the change in PD and CAL parameters is due to the corticotomy procedure performed. Appropriate qualification of patients as well as appropriate microsurgical techniques contributed to the obtained results. It is difficult to obtain a large group of patients with the presented orthodontic defect and willing to start complex treatment. This is due to both economic constraints and the specificity of the performed treatment. The procedures applied by us are associated with a large number of visits and fear of surgery.

The favourable changes in the periodontium may result from the process of tissue remodelling, the expression of which is the highest immediately after the surgical procedure $[11,33,40,58-60]$. However, our results should be analyzed cautiously due to the fact that they constitute the first long-term data evaluating the condition of periodontium after combined surgical and orthodontic treatment. Nevertheless, these results highlight the fact that while making a treatment plan for patients with transverse maxillary deficiency, the corticotomy procedure should be considered as a potential form of preventing the development of bone dehiscence and gingival recession.

Author Contributions: Conceptualization M.E.S. and M.P.; project administration, funding acquisition, resources, M.P.; methodology, M.E.S. and M.P.; data curation, M.E.S., A.B., B.B.-M. and E.W.-S.; formal analysis, M.E.S.; investigation, M.E.S.; software, J.K.P.; supervision, M.P. and J.K.P.; validation, J.K.P.; visualization, B.B.-M. and E.W.-S.; writing of original draft, M.E.S. and A.B.; writing with review and editing, M.P. and J.K.P. All authors have read and agreed to the published version of the manuscript.

Funding: The study was supported by Medical University of Białystok.

Institutional Review Board Statement: The study was conducted in accordance with the Helsinki Declaration of 1975, as revised in 2000, and was reviewed and approved by the local ethical committee of the Medical University of Białystok (Ethics Committee No.: R-I-002/344/2011). All the patients gave their written informed consent for participation in the study.

Informed Consent Statement: Informed consent was obtained from all subjects involved in the study.

Data Availability Statement: The data presented in this study are available in the article.

Conflicts of Interest: The authors declare that there is no conflict of interest in this study. 


\section{References}

1. Renkema, A.M.; Fudalej, P.S.; Renkema, A.; Kiekens, R.; Katsaros, C. Development of labial gingival recessions in orthodontically treated patients. Am. J. Orthod. Dentofac. Orthop. 2013, 143, 206-212. [CrossRef] [PubMed]

2. Wang, C.W.; Yu, S.H.; Mandelaris, G.A.; Wang, H.L. Is periodontal phenotype modification therapy beneficial for patients receiving orthodontic treatment? An American Academy of Periodontology best evidence review. J. Periodontol. 2020, 91, 299-310. [CrossRef] [PubMed]

3. Ackerman, J.L.; Proffit, W.R. Soft tissue limitations in orthodontics: Treatment planning guidelines. Angle Orthod. 1997, 67, 327-336. [PubMed]

4. Jepsen, S.; Caton, J.G.; Albandar, J.M.; Bissada, N.F.; Bouchard, P.; Cortellini, P.; Demirel, K.; de Sanctis, M.; Ercoli, C.; Fan, J.; et al. Periodontal manifestations of systemic diseases and developpmental and acquired conditions: Consensus report of workgroup 3 of the 2017 World Workshop on the Classification of Periodontal and Peri-Implant Diseases and Conditions. J. Periodontol. 2018, 89 (Suppl. S1), S237-S248. [CrossRef]

5. Kim, D.M.; Neiva, R. Periodontal soft tissue non-Root coverage procedures: A systematic review from the AAP Regeneration Workshop. J. Periodontol. 2015, 86 (Suppl. S2), S56-S72. [CrossRef] [PubMed]

6. Imber, J.C.; Kasaj, A. Treatment of gingival recession: When and How? Int. Dent. J. 2021, 71, 178-187. [CrossRef]

7. Kassab, M.M.; Badawi, H.; Dentino, A.R. Treatment of Gingival Recession. Dent. Clin. N. Am. 2010, 54, 129-140. [CrossRef]

8. Pini Prato, G.P.; Franceschi, D.; Cortellini, P.; Chambrone, L. Long-Term evaluation (20 years) of the outcomes of subepithelial connective tissue graft plus coronally advanced flap in the treatment of maxillary single recession-Type defects. J. Periodontol. 2018, 89, 1290-1299. [CrossRef]

9. Bhedasgoankar, S.; Kapadia, J.; Bhandari, S. Gingival augmentation procedure prior to fixed orthodontic treatment. J. Int. Clin. Dent. Res. Organ. 2011, 3, 74-77. [CrossRef]

10. Boyd, R.L. Mucogingival considerations and their relationship to orthodontics. J. Periodontol 1978, 49, 67-76. [CrossRef]

11. Frost, H.M. The regional acceleratory phenomenon: A review. Henry Ford Hosp. Med. J. 1983, 31, 3-9. [PubMed]

12. Kernitsky, J.R.; Ohira, T.; Shosho, D.; Lim, J.; Bamashmous, A.; Dibart, S. Corticotomy depth and regional acceleratory phenomenon intensity: A preliminary study. Angle Orthod. 2021, 91, 206-212. [CrossRef] [PubMed]

13. Frost, H.M. The biology of fracture healing: An overview for clinicians. Part I Clin. Orthop. Relat. Res. 1989, $248,283-293$. [CrossRef]

14. Frost, H.M. The biology of fracture healing: An overview for clinicians. Part II Clin. Orthop. Relat. Res. 1989, 248, 294-309. [CrossRef]

15. Wilcko, W.M.; Ferguson, D.J.; Bouquot, J.E.; Wilcko, M.T. Rapid orthodontic decrowding with alveolar augmentation: Case report. World J. Orthod. 2003, 4, 197-205.

16. Khandelwal, A.; Thomas, B.; Ramesh, A.; Talwar, A. Treatment of bimaxillary protrusion using corticotomy-Assisted orthodontics: An interdisciplinary approach. Indian J. Multidiscip. Dent. 2018, 8, 39-43.

17. Nimeri, G.; Kau, C.H.; Abou-Kheir, N.S.; Corona, R. Acceleration of tooth movement during orthodontic treatment a frontier in orthodontics. Prog. Orthod. 2013, 14, 42. [CrossRef]

18. Amit, G.; Jps, K.; Pankaj, B.; Suchinder, S.; Parul, B. Periodontally accelerated osteogenic orthodontics (PAOO)—A review. J. Clin. Exp. Dent. 2012, 4, 292-296. [CrossRef]

19. Prabhakar, R.; Karthikeyan, M.K.; Saravanan, R.; Kannan, K.S.; Arun Raj, M.R. Anterior maxillary intrusion and retraction with corticotomy-Facilitated orthodontic treatment and burstone three piece intrusive arch. J. Clin. Diagn. Res. 2013, 7, 3099-3101. [CrossRef]

20. Yaffe, A.; Fine, N.; Binderman, I. Regional accelerated phenomenon in the mandible following mucoperiosteal flap surgery. J. Periodontol. 1994, 65, 79-83. [CrossRef]

21. Lee, W.; Karapetyan, G.; Moats, R.; Yamashita, D.D.; Moon, H.B.; Ferguson, D.J.; Yen, S. Corticotomy-Osteotomy-Assisted Tooth Movement microCTs Differ. J. Dent. Res. 2008, 87, 861-867. [CrossRef]

22. Wilcko, M.T.; Wilcko, W.M.; Pulver, J.J.; Bissada, N.F.; Bouquot, J.E. Accelerated Osteogenic Orthodontics Technique: A 1-Stage Surggically Facilitated Rapid Orthodontic Technique with Alveolar Augmentation. J. Oral. Maxillofaci. Surg. 2009, 67, 2149-2159. [CrossRef] [PubMed]

23. Vardimon, A.D.; Nemcovsky, C.E.; Dre, E. Orthodontic tooth movement enhaces bone healing of surgical bony defects in rats. J. Periodontol. 2001, 72, 858-864. [CrossRef] [PubMed]

24. Gantes, B.; Rathbun, E.; Anholm, M. Effects on the periodontium following corticotomy-Facilitated orthodontics. Case reports. J. Periodontol. 1990, 61, 234-238. [CrossRef] [PubMed]

25. Sulewska, M.; Duraj, E.; Bugała- Musiatowicz, B.; Waszkiewicz -Sewastianik, E.; Milewski, R.; Pietruski, J.; Sajewicz, E.; Pietruska, M. Assesment of the effect of the corticotomy-Assisted orthodontic treatment on the maxillary periodontal tissue in patients with malocclusions with transverse maxillary deficiency: A case series. BMC Oral Health 2018, 18, 162. [CrossRef]

26. Charavet, C.; Lecloux, G.; Bruwier, A.; Rompen, E.; Maes, N.; Limme, M.; Lambert, F. Localized Piezoelectric Alveolar Decortication for Orthodontic Treatment in Adults: A Randomized Controlled Trial. J. Dent. Res. 2016, 95, 1003-1009. [CrossRef] [PubMed]

27. Shoreibah, E.A.; Ibrahim, S.A.; Attia, M.S.; Diab, M.M. Clinical and radiographic evaluation of bone grafting in corticotomyFacilitated orthodontics in adults. J. Int. Acad. Periodontol. 2012, 14, 105-113. 
28. Shoreibah, E.A.; Salama, A.E.; Attia, M.S.; Abu-Seida, S.M. Corticotomy-Facilitated orthodontics in adults using a further modified technique. J. Int. Acad. Periodontol. 2012, 14, 97-104.

29. Aksakalli, S.; Calik, B.; Kara, B.; Ezirganli, S. Accelerated tooth movement with piezocision and its periodontal-Transversal effects in patients with Class II malocclusion. Angle Orthod. 2016, 86, 59-65. [CrossRef]

30. Abbas, I.T.; Moutamed, G.M. Acceleration of orthodontic tooth movement by alveolar corticotomy using piezosurgery. J. Am. Sci. 2012, 8, 13-19.

31. Aristizibal, J.F.; Bellaiza, W.; Ortiz, M.A.; Franco, L. Clinical and systemic effects of periodontally accelerated osteogenic orthodontics: A pilot study. Int. J. Odontostomatol. 2016, 10, 119-127. [CrossRef]

32. Abbas, N.H.; Sabet, N.E.; Hassan, I.T. Evaluation of corticotomy-Facilitated orthodontics and piezocision in rapid canine retraction. Am. J. Orthod. Dentofac. Orthop. 2016, 149, 473-480. [CrossRef] [PubMed]

33. Aboul-Ela, S.M.; El-Beialy, A.R.; El-Sayed, K.M.; Selim, E.M.; El-Mangoury, N.H.; Mostafa, Y.A. Miniscrew implant-Supported maxillary canine retraction with and without corticotomy-Facilitated orthodontics. Am. J. Orthod. Dentofac. Orthop. 2011, 139, 252-259. [CrossRef] [PubMed]

34. Fischer, T.J. Orthodontic treatment acceleration with corticotomyassisted exposure of palatally impacted canines. Angle Orthod. 2007, 77, 417-420. [CrossRef]

35. Cassetta, M.; Giansanti, M.; Di Mambro, A.; Calasso, S.; Barbato, E. Minimally invasive corticotomy in orthodontics using a three-Dimensional printed CAD/CAM surgical guide. Int. J. Oral Maxillofac. Surg. 2016, 45, 1059-1064. [CrossRef]

36. Cortellini, P.; Pini Prato, G.; Tonetti, M.S. The modified papilla preservation technique. A new surgical approach for interproximal regenerative procedures. J. Periodontol. 1995, 66, 261-266. [CrossRef]

37. da Silva, S.C.; Joly, J.C.; de Lima, A.F.M.; Tatakis, D.N. Root coverage using the coronally positioned flap with or without a subepithelial connective tissue graft. J. Periodontol. 2004, 75, 413-419. [CrossRef]

38. Cassetta, M.; Pandolfi, S.; Giansanti, M. Minimally invasive corticotomy in orthodontics: A new technique using a CAD/CAM surgical template. Int. J. Oral Maxillofac. Surg. 2015, 44, 830-833. [CrossRef]

39. Hoogeveen, E.J.; Jansma, J.; Ren, Y. Surgically facilitated orthodontic treatment: A systematic review. Am. J. Orthod. Dentofac. Orthop. 2014, 145 (Suppl. S4), 51-64. [CrossRef]

40. Hassan, A.H.; Al-Fraidi, A.A.; Al-Saeed, S.H. Corticotomy-Assisted orthodontic treatment: Review. Open Dent. J. 2010, 4, 159-164. [CrossRef]

41. Aljhani, A.S.; Zawawi, K.H. Nonextraction treatment of severe crowding with the aid of corticotomy-Assisted orthodontics. Case Rep. Dent. 2012, 694527, 8. [CrossRef]

42. Germeç, D.; Giray, B.; Kocadereli, I.; Enacar, A. Lower incisor retraction with a modified corticotomy. Angle Orthod. 2006, 76, 882-890.

43. Wilcko, M.T.; Wilcko, W.M.; Bissada, N.F. An evidence-Based analysis of periodontally accelerated orthodontic and osteogenic techniques: A synthesis of scientific perspectives. Semin. Orthod. 2008, 14, 305-316. [CrossRef]

44. Nowzari, H.; Yorita, F.K.; Chang, H.C. Periodontally accelerated osteogenic orthodontics combined with autogenous bone grafting. Compend. Contin. Educ. Dent. 2008, 29, 200-218. [PubMed]

45. Iino, S.; Sakoda, S.; Miyawaki, S. An adult bimaxillary protrusion treated with corticotomy-Facilitated orthodontics and titanium miniplates. Angle Orthod. 2006, 76, 1074-1082. [PubMed]

46. Oliveira, D.D.; de Oliveira, B.F.; de Araújo Brito, H.H.; de Souza, M.M.G.; Medeiros, P.J. Selective alveolar corticotomy to intrude overerupted molars. Am. J. Orthod. Dentofac. Orthop. 2008, 133, 902-908. [CrossRef] [PubMed]

47. Rekhi, U.; Catunda, R.Q.; Gibson, M.P. Surgically accelerated orthodontic techniques and periodontal response: A systematic review. Eur. J. Orthod. 2020, 635-642. [CrossRef] [PubMed]

48. Bahammam, M.A. Effectiveness of bovine-Derived xenograft versus bioactive glass with periodontally accelerated osteogenic orthodontics in adults: A randomized, controlled clinical trial. BMC Oral Health 2016, 16, 126. [CrossRef] [PubMed]

49. Binderman, I.; Adut, M.; Zohar, R.; Bahar, H.; Faibish, D.; Yaffe, A. Alveolar bone resorption following coronal versus apical approach in a mucoperiosteal flap surgery procedure in the rat mandible. J. Periodontol. 2001, 72, 1348-1353.

50. Alkan, O.; Kaya, Y.; Tunca, M.; Keskinc, S. Changes in the gingival thickness and keratinized gingival width of maxillary and mandibular anterior teeth after orthodontic treatment. Angle Orthod. 2021, 91, 459-467. [CrossRef]

51. Coatoam, G.W.; Behrents, R.G.; Bissada, N.F. The width of keratinized gingiva during orthodontic treatment: Its significance and impact on periodontal status. J. Periodontol. 1981, 52, 307-313. [CrossRef]

52. Wang, G.N.; Jiao, J.; Zhou, Y.H.; Shi, J. Effect of orthodontic tooth movement on keratinized gingival width. Beijing Da Xue Xue Bao Yi Xue Ban 2019, 51, 931-936. [PubMed]

53. Wilcko, W.M.; Wilcko, T.; Bouquot, J.E.; Ferguson, D.J. Rapid orthodontics with alveolar reshaping: Two case reports of decrowding. Int. J. Period. Restor. Dent. 2001, 21, 9-19.

54. Bogoch, E.; Gschwend, N.; Rahn, B.; Moran, E.; Perren, S. Healing of cancellous bone osteotomy in rabbits-part I: Regulation of bone volume and the regional acceleratory phenomenon in normal bone. J. Orthop. Res. 1993, 11, 285-291. [CrossRef] [PubMed]

55. Moreau, N.; Charrier, J.B. Bone formation and corticotomy-Induced accelerated bone remodeling: Can alveolar corticotomy induce bone formation? Orthod. Fr. 2015, 86, 113-120. [CrossRef] [PubMed]

56. Medeiros, R.B.; Pires, F.R.; Kantarci, A.; Capelli, J., Jr. Tissue repair after selective alveolar corticotomy in orthodontic patients: A preliminary study. Angle Orthod. 2018, 88, 179-186. [CrossRef] 
57. Hannequin, R.; Ouadi, E.; Racy, E.; Moreau, N. Clinical follow-Up of corticotomy accelerated Invisalign orthodontic treatment with Dental Monitoring. Am. J. Orthod. Dentofac. Orthop. 2020, 158, 878-888. [CrossRef]

58. Bhattacharya, P.; Bhattacharya, H.; Anjum, A.; Bhandari, R.; Agarwal, D.K.; Gupta, A.; Ansar, J. Assessment of corticotomy facilitated tooth movement and changes in alveolar bone thickness-a CT scan study. J. Clin. Diagn. Res. 2014, 8, ZC26-ZC30.

59. Sebaoun, J.D.; Kantarci, A.; Turner, J.W.; Carvalho, R.S.; Van Dyke, T.E.; Ferguson, D.J. Modeling of trabecular bone and lamina dura following selective alveolar decortication in rats. J. Periodontol. 2008, 79, 1679-1688. [CrossRef]

60. Baloul, S.S.; Gerstenfeld, L.C.; Morgan, E.F.; Carvalho, R.S.; Van Dyke, T.E.; Kantarci, A. Mechanism of action and morphologic changes in the alveolar bone in response to selective alveolar decortication-Facilitated tooth movement. Am. J. Orthod. Dentofac. Orthop. 2011, 139 (Suppl. S4), 83-101. [CrossRef] 